\title{
Silicon and Mechanisms of Plant Resistance to Insect Pests
}

\author{
Fadi Alhousari * and Maria Greger ${ }^{\text {iD }}$ \\ Department of Ecology, Environment and Plant Science, Stockholm University, 10691 Stockholm, Sweden; \\ maria.greger@su.se \\ * Correspondence: fadi.alhousari@su.se; Tel.: +46-735-752-490
}

Received: 16 January 2018; Accepted: 11 April 2018; Published: 13 April 2018

\begin{abstract}
This paper reviews the most recent progress in exploring silicon-mediated resistance to herbivorous insects and the mechanisms involved. The aim is to determine whether any mechanism seems more common than the others as well as whether the mechanisms are more pronounced in silicon-accumulating than non-silicon-accumulating species or in monocots than eudicots. Two types of mechanisms counter insect pest attacks: physical or mechanical barriers and biochemical/molecular mechanisms (in which $\mathrm{Si}$ can upregulate and prime plant defence pathways against insects). Although most studies have examined high Si accumulators, both accumulators and non-accumulators of silicon as well as monocots and eudicots display similar Si defence mechanisms against insects.
\end{abstract}

Keywords: silicon; plant resistance; insects; HIPVs; physical defence; induced defence

\section{Introduction}

Arthropod pests are biotic stressors, attacking plants above and below ground and eventually reducing yield quantity and quality [1]. Plants counteract insect attacks both directly and indirectly. Many of these defences are regulated by signalling pathways in which phytohormones have central roles. Direct defences associated with host morphological traits such as trichomes, wax and cell wall lignification affect insect feeding behaviour and performance. These plant characteristics constitute physical or mechanical feeding barriers as the first line of defence. The second line of defence comprises secondary metabolites (e.g., phenols and lignin, which affect insect growth and development), with various enzymes, such as polyphenol oxidase (PPO), phenylalanine ammonia lyase (PAL) and peroxidase (POD), being involved in their synthesis. Indirect defences are mediated by host plant volatiles or by herbivore-induced plant volatiles (HIPVs) released in response to insect feeding. HIPVs, modulated by the JA pathway, promote biological control by attracting predators and parasitoids of the insect pests [2-8]. Both direct and indirect responses to insect attacks contribute to plant resistance and may be constitutively present or induced [4].

In addition, exploiting plant resistance can represent an economically and ecologically efficient approach to integrated pest management (IPM). One way to improve effective resistance is to supplement with silicon ( $\mathrm{Si}$ ). $\mathrm{Si}$ is an important element in plant nutrition and is the most common element, after oxygen, on earth. Silicic acid, that is, $\mathrm{Si}(\mathrm{OH})_{4}$, is the bioavailable form of silicon in soil solution that is taken up by plant roots $[9,10]$. $\mathrm{Si}$ is translocated through the xylem to the shoots where it condenses into polymerized silica gel [11]. According to their ability to accumulate Si, plants are classified as high (10-15\%), medium (1-3\%) and non- $(<1 \%$ Si dry mass, $\mathrm{dm}) \mathrm{Si}$ accumulators [12]. High Si accumulators include wetland grasses (e.g., rice, bamboo and sugar cane) and medium accumulators terrestrial grasses (e.g., wheat), while low accumulators are commonly eudicots. 
It is now well established that $\mathrm{Si}$ enhances plant resistance and reduces plant damage caused by pathogens, insect pests and non-insect pests through the mediation and upregulation of both resistance mechanisms that are constitutive (i.e., irrespective of insect presence) and induced (i.e., in response to insect attack) $[13,14]$. To date, a range of examples documents the ability of Si to enhance the resistance of both monocotyledonous crops and numerous dicot plant species to insect pests of diverse feeding guilds belonging to Lepidoptera [8,15,16], Hemiptera [17], Homoptera [18], Diptera [19], Thysanoptera and Coleoptera [20] as well as to non-insect pests [21,22].

Si deposition patterns within plant tissues led to the hypothesis of mechanical or physical barriers to insect feeding, as silica makes plant tissues difficult for insects to efficiently chew, penetrate and digest. In addition, silica's beneficial roles in plant physiology, regulation of defence-related enzymes, plant hormone signalling and alteration of plant volatile blends elucidate the association of Si with biochemical/molecular defence mechanisms ([15,20,23-25]; Figure 1).

In this review, we describe the mode of action of $\mathrm{Si}$ in plant resistance mechanisms and highlight how Si bolsters plant defences against insect pests of different feeding guilds in both mono- and dicots.

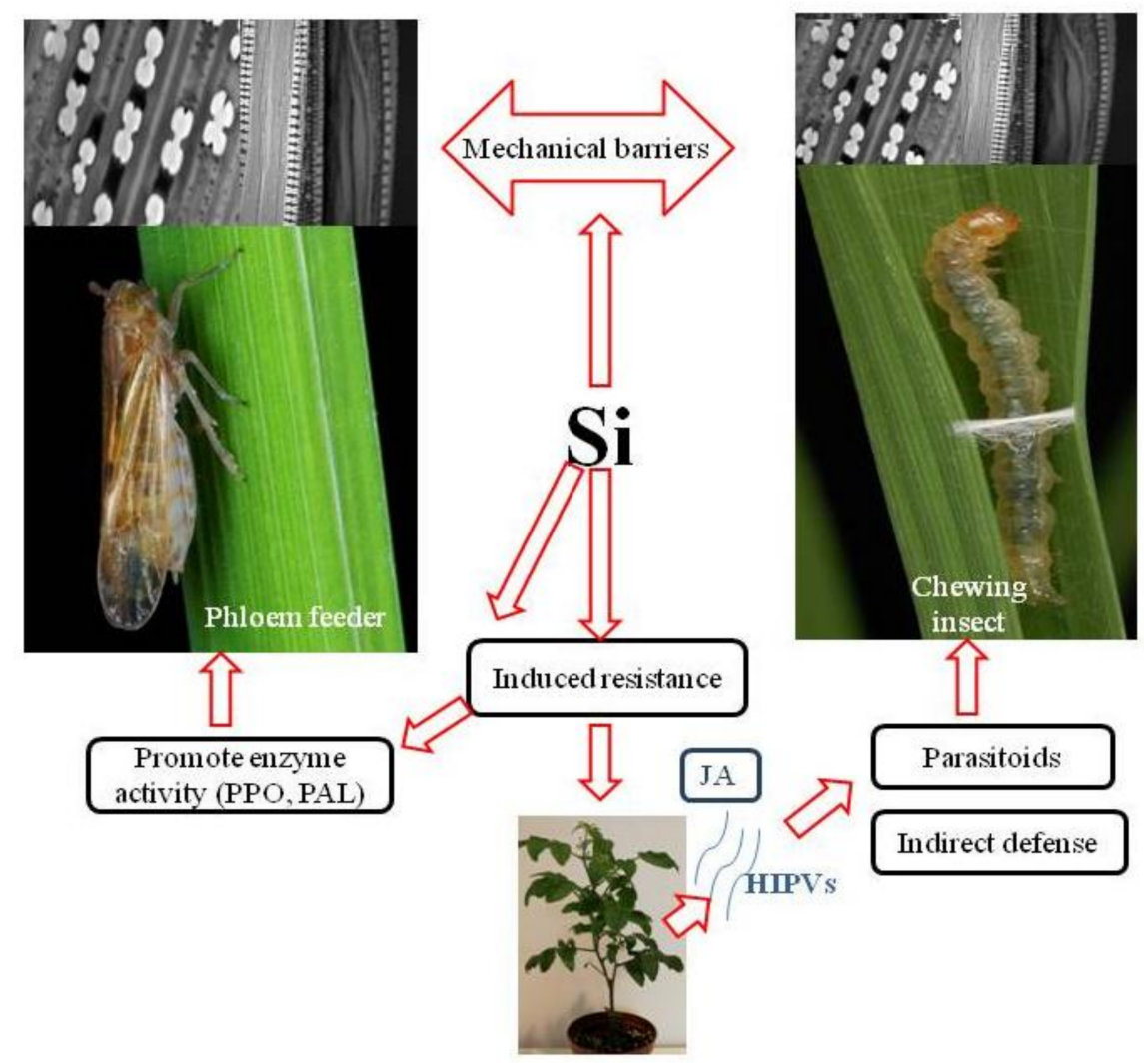

Figure 1. Silicon mediated mechanisms of plant resistance to insect pests. (PPO) polyphenol oxidase, (PAL) phenylalanine ammonia lyase, (HIPVs) herbivore-induced plant volatiles, (JA) jasmonate phytohormone.

\section{Formation of Physical Barriers to Insects}

The physical resistance mechanism was first proposed with reference to fungal diseases in eudicots and then generalized to monocots (see mini-review by Fauteux et al. [23]). The bioavailable Si absorbed by plants generally strengthens direct and indirect plant resistance to insect pests via the deposition of $\mathrm{SiO}_{2}$ as biogenic opals (phytoliths), primarily in the epidermal cells of leaves, stems and roots [14]. Silicon is deposited as a $2.5-\mu \mathrm{m}$-thick layer just beneath the cuticle layer $(0.1 \mu \mathrm{m}$ thick), forming a silicon-cuticle double layer in rice leaf blades ([26]; Figure 2). Consequently, phytoliths promote 
cell-wall strengthening. The abrasiveness of silicified leaves and other plant tissues associated with protection, storage, support and strengthening leads to the increased irreversible wear of mouthparts when insects are feeding, therefore deterring chewing insects. Mouthpart wear due to Si treatment can vary according to feeding habit. For instance, Spodoptera exempta larvae fed a silica-rich diet displayed increased mandible wear [27]. In contrast, no damage was observed in the incisor teeth of the mandibles, imaged by scanning electron microscopy (SEM), of leaf miner (Tuta absoluta) larvae fed Si-treated tomato leaves. In other words, this could be due to the specific feeding strategy, since leaf miners feed on soft tissues between epidermal cell layers [4,28].

Moreover, a high Si level could influence the availability of other nutrients in plants, such as nitrogen, inducing insects to consume greater quantities of high-Si-treated plants. In addition, a high silica content in plant tissue reduces its digestibility and palatability, consequently slowing the insect growth rate $[15,27,29]$.

The insect midgut epithelium plays an important role in food digestion and conversion to nutrients by digestive enzymes; moreover, it is a site for insecticide detoxification [30]. Si could damage the ultrastructure of the midgut epithelium, mainly through detachment of epithelial cells from the basement membrane as observed in larvae of the leaf miner Tuta absoluta fed Si-treated leaves of tomato (an Si excluder) [28]. This negatively affects the nutrient absorption and growth rate. It could also prevent insects from developing resistance to pesticides and could increase the efficacy of chemical controls combined with Si.

On the other hand, $\mathrm{Si}$ is involved in toughening plant tissues, acting indirectly by delaying insect penetration of host tissues and thus increasing the duration of insect exposure to natural enemies, adverse environmental conditions and chemical controls. In sugarcane, Si accumulated in the stem epidermal tissue of the internode and root band increased the resistance to Eldana saccharina by reducing larval stalk penetration $[15,31]$.

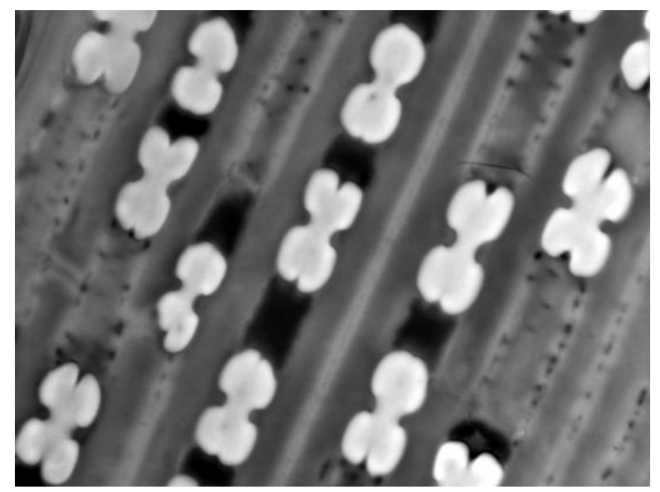

(a)

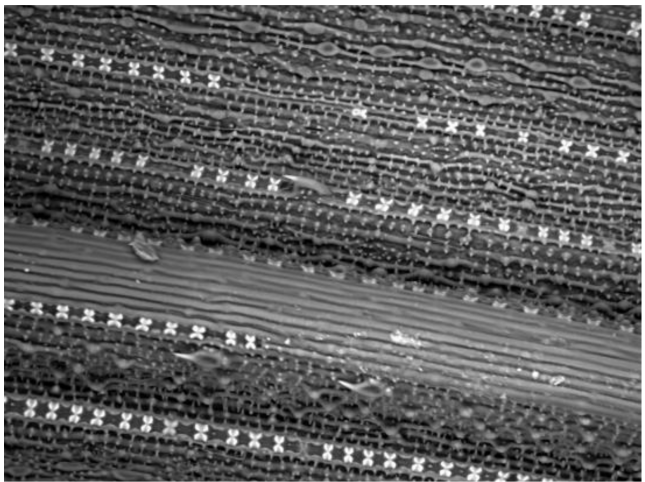

(b)

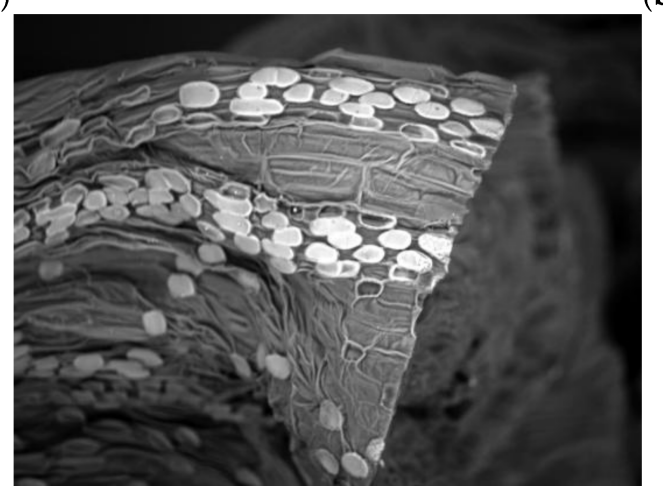

(c)

Figure 2. Scanning electron micrographs of maize (a); rice (b); and wheat (c) sheath surfaces showing silica cell form and deposition. 
Silica could also protect the resources in the chlorenchyma cells of grasses against locusts (Schistocerca gregaria) by reducing mechanical breakdown of the leaf. In addition, Si can also help increase grasses resistance by reducing chlorophyll released after grinding and retained more after passing through the gut of locusts [32].

In plants of coffee, a dicot, Si may also enhance a plant morphological trait that confers resistance to insect feeding through the formation of a thicker wax layer on the abaxial surface of coffee seedlings [33].

Furthermore, the arrangement and distribution of silicified microstructures, together with their pattern and location in plant tissues, were considered more effective at conferring resistance than was their actual Si content, effectively delaying plant penetration by insects and thereby decreasing plant susceptibility to herbivore insect damage. Si amendment increases the content in leaf sheaths and the histological parameters of silica cells. Such as rows of silica cells per $\mathrm{mm}^{2}$, number of silica cells per 1-mm row and area of silica cells, consequently maximizes the physical barrier to insect pests approximately tenfold in rice $[7,31,34]$.

SEM investigation of Si-treated rice plants revealed ladder-like structures of dumbbell-shaped silica and Si-enriched trichomes. These microstructures in rice impart strength to the plant and serve as a mechanical barrier against stem borers and planthoppers ([11,35]; Figure 2). The sharp Si-enriched trichomes mechanically affect the insects, impeding their movement and settlement and possibly negatively affecting their oviposition preference and feeding rate [36]. In addition, glandular trichomes function as deterrents by secreting secondary metabolites (e.g., flavonoids, terpenoids and alkaloids) that can be poisonous and repellent to many insect pests, thus increasing resistance [37].

Likewise, our SEM observations revealed various forms of silica cells, which are butterfly shaped in maize and rice leaves and oval in wheat (Figure 2). These different shapes and distributions of silicified microstructures could be attributed to the Si concentration and plant growth stage. Si deposition could shift from small cells to bulliform cells and trichomes as the Si content increased in rice plants [35]. Furthermore, Si cells differentiation and accumulation expected to be regulated by JA [24].

Si additionally has physiological, biological and behavioural consequences in the insects. It is possible to affect the development of insect pests, their population intensity and feeding behaviour. Larval survival and pupation rate of the rice leaf folder Cnaphalocrocis medinalis Guenée (Lepidoptera: Pyralidae) were significantly reduced by feeding on rice plants supplemented with Si [8]. Extended larval development means that instars lack the food quality and food conversion efficiencies. These elements enhance the resistance in a rice variety (Taichung Native 1, TN1) susceptible to the rice leaf folder $C$. medinalis Guenée. Si amendment in rice is equally responsible for physiological and behavioural implications in the phloem-feeding insects by reducing the fertility, honeydew excretion quantity and settled insect number of the brown planthopper Nilaparvata lugens Stål. (Homoptera: Delphacidae). Moreover, a high Si addition could affect the sucking behaviour by prolonging the stylet pathway and time needed to achieve the first phloem puncture and shortening the durations of phloem puncture and phloem ingestion [18,38].

Among other biological parameters, the rate of fecundity was the most affected in Spodoptera frugiperda female derived from caterpillars feeding on corn diet treated with Si [39].

Not only shoots but also roots can defend against insect attacks. Interestingly, high root Si concentrations can effectively reduce the feeding and relative growth rate performance of the sugarcane root-feeding insect, the greyback canegrub (Dermolepida albohirtum) [40,41].

To sum up, based on the above studies and findings, it can be concluded that $\mathrm{Si}$ confers resistance to plants species against insect pests by forming physical barriers (in both mono- and dicots) and eventually impacts on insect feeding behaviour and performance.

\section{Silicon-Mediated Induced Resistance to Insects}

The use of plant resistance inducers is considered an environmentally friendly strategy to efficiently decrease insect pest populations. In addition to acting as a mechanical barrier, $\mathrm{Si}$ can 
reduce pest damage by enhancing the induced chemical defences of plants following insect attack. Silicon acts as an abiotic elicitor of systemic stress signals, mediated by phytohormone pathways, leading to the efficient synthesis of defensive compounds [23]. Plant defences are complex and can vary according to the feeding strategy of the insect pests [42].

Each plant attacker has its own signal signature. The common phytohormones salicylic acid (SA), jasmonic acid (JA) and ethylene play primary roles in orchestrating plant defence responses [43]. JA is suggested to regulate defences against both cell-content-feeding and tissue-chewing insects [44,45]. Defence against phloem-feeding insects is regulated by both SA and JA signals [46]. Interestingly, evidence for the strong interaction between $\mathrm{Si}$ and JA against insects is accumulating [24,47], this being considered a possible mechanism by which $\mathrm{Si}$ enhances resistance to insect pests. Moreover, Si-induced resistance could also be expressed by priming the host plant to defend itself against insect pests attack [20,48-50]. Priming is a process of sensitizing and preparing the plant's defence responses to be faster and stronger to future herbivorous insect threats [6,24].

Next, we will focus on recent studies of the role of $\mathrm{Si}$ in induced plant defence responses to chewing and phloem-feeding insect pests.

\subsection{Si and Chewing Insect Pests}

Plant secondary metabolites play a vital role in plant interactions with insects and their natural enemies. In addition, plant volatile emissions can be constitutive or can be induced in response to stresses. Regardless of the emission mode, volatiles are involved in defence reactions triggered by herbivores [51].

In tritrophic systems, chemical compounds are emitted by plants in reaction to insect-induced damage in the form of HIPVs. These compounds can act either as direct attractants or repellents of insects and thus may be used as host-finding cues by entomophagous predators and parasitoids of insect pests ([52,53]; Figure 1).

Si may trigger different plant species to emit, amplify, and/or alter HIPVs. In response to feeding by the rice leaf folder (C. medinalis), a wild-type rice plant supplied with Si mounts a strong indirect defence based on HIPV production. Among which are hexanal 2-ethyl, $\alpha$-bergamotene, $\beta$-sesquiophellandrene and cedrol, produced in significantly smaller amounts in infested Si-treated plants [47].

These changed HIPV profiles then significantly enhanced the attraction of adult females of the parasitoids Trathala flavo-orbitalis and Microplitis to the Si-treated plants attacked by C. medinalis. The signalling pathways that allow rice plants to mount resistance against the chewing insect C. medinalis are JA dependent [47]. To elaborate, Si and JA linked strongly to different components of rice defensive system. This can be expressed in increasing the levels of transcripts encoding defence genes, the activities of defence-related enzymes (PPO, POD and trypsin protease inhibitor), in addition to HIPVs alteration [24].

Under both laboratory and semi-field conditions, Si-treated plants attracted significantly more of the predator Dicranolaius bellulus to cucumber plants (a medium Si-accumulator dicot) infested with Helicoverpa armigera [54].

Another well-established example of this phenomenon is in Vitis vinifera L., a dicot and Si non-accumulator. A positive correlation was observed between plant tissue Si content and attraction of the predator D. bellulus to grapevines infested with Epiphyas postvittana. Moreover, seven volatile compounds emitted in Phalaenoides glycinae-infested grapevines were identified. One of them, $\mathrm{n}$-heptadecane, was released in significant amounts only by Si-fertilized grapevines [55].

The above-mentioned literature revealed that Si application could notably alter HIPVs in both mono and dicots plant species while sharing the same response against chewing insect pests. 


\subsection{Si and Phloem Feeders}

Insect phloem feeding can be inhibited at three stages: before food ingestion, during ingestion (via the activity of salivary enzymes), or after digestion and food absorption. Electrical penetration graphs (EPGs) allowed monitoring of the behavioural responses of insects during probing and feeding and exploration of interference with probing by chemical or physical factors within the plant tissues and of the localization of resistance within plant tissues [56].

Based on EPG findings, reduction of both duration of phloem ingestion and proportion of the brown planthopper ( $N$. lugens) individuals ingesting phloem were observed on rice amended with $\mathrm{Si}$. Silicon-induced resistance to $N$. lugens is associated with increased accumulation of callose. Callose deposition in the sieve tubes blocks the mass flow of phloem and prevents phloem sap leakage following feeding puncture [38,57].

$\mathrm{Si}$ may further involve in biochemical and physiological changes that triggered by $\mathrm{H}_{2} \mathrm{O}_{2}$ in rice plant tissue upon N. lugens attack. Si amendment could obviously alleviate the stress resulting from $N$. lugens by slowing the increase of malondialdehyde (MDA) concentrations, the physiological index of plants under stress. Moreover, Si plays a role in scavenging the reactive oxygen species (ROS) by priming the activities of antioxidant enzymes. Immediately after N. lugens attack, The PPO and PAL activities trigger and catalyse the oxidation of phenols to quinines. It can reduce the palatability of plant tissues and eventually restrict insect development [4,7].

Similarly, treating wheat plants with silicon could negatively affect the feeding behaviour and population increase rate of the greenbug Schizaphis graminum Rondani (Hemiptera: Aphididae). Suppressing the percentage of $S$. graminum reached the phloem ingestion phase indicates that Si-induced resistance possibly localized at the phloem level. The Si-induced mechanism in wheat plants could be explained by increasing the activities of POD, PPO and PAL. The POD is involved in plant defence via lignification, suberization and production of ROS and quinones, which exhibit antibiotic properties $[58,59]$.

Si-induced resistance has also been reported in eudicots as well as monocots. In cucumbers, $\mathrm{Si}$ may induce the synthesis of defence chemicals, reducing the preference of Bemisia tabaci (Gennadius) (Hemiptera: Aleyrodidae) for oviposition, expanding the insects' developmental period and increasing nymphal mortality [60].

Briefly stated, the above studies clearly show that Si supplementations can induce several plant defence responses, to phloem-feeding insect pests, by modulating the plant antioxidant defence systems and secondary metabolites.

\section{Si-Induced Resistance below Ground}

Like aboveground plant parts, belowground portions of plants are also face threats, namely, from root-feeding insects. Interestingly, the attack of aboveground plant shoots by insects can also result in root responses defending against root feeders. Induced defences mediated by JA signalling have been found to improve rice resistance to the rice water weevil (Lissorhoptrus oryzophilus), whose larvae feed on rice roots under flooded conditions [61]. Accordingly, the interaction between both constitutive and Si-induced resistance could strongly enhance plant resistance and reduce damage caused by root-feeding insects.

Below ground, the larvae of Diabrotica speciosa (Coleoptera: Chrysomelidae) damage plant roots and create holes in the tubers of the potato (Solanum tuberosum L.), whereas the adults consume the leaves. Foliar applications of silicic acid, an inducer of plant resistance, increased plant protection against defoliators and decreased tuber damage, reducing the number of holes in the tubers of treated plants. This reduction in tuber attack was correlated with the reduced leaf damage in the plants treated with silicic acid [62].

A recent study demonstrated that Si nanoparticles (SiNPs) may induce defence responses in the root system [25]. The authors demonstrated that SiNPs increased the lignification of the root cell wall 
in the dicot fenugreek, Trigonella foenum-graecum (Fabaceae), together with increasing the expression of the root defensive gene $(t f g d 1)[25,63]$.

Moreover, root-applied Si optimizes the mechanical characteristics of rapeseed by increasing the root diameter, breaking strength and expression levels of the key genes related to stem lignin biosynthesis [64].

\section{Summary and Future Research}

As described here, Si has a central role in boosting plants' direct and indirect defences against many insect pests via two Si-based mechanisms: strengthened physical or mechanical barriers and biochemical/molecular mechanisms that induce plant defence responses. The relevant studies have been performed in various plant species, often using insects with diverse feeding strategies. Taken together, we draw the overall conclusion that plants employ both Si-based resistance mechanisms synergistically rather than singly, relying on combined physical, chemical and biochemical mechanisms to reduce damage by insect pests.

For example, the brown planthopper is affected by both the physical barrier of silica cells and by the induced resistance mediated by Si in rice as a model high Si accumulator (Table 1).

Table 1. Si-mediated plant resistance mechanisms and defensive responses reported in the literature.

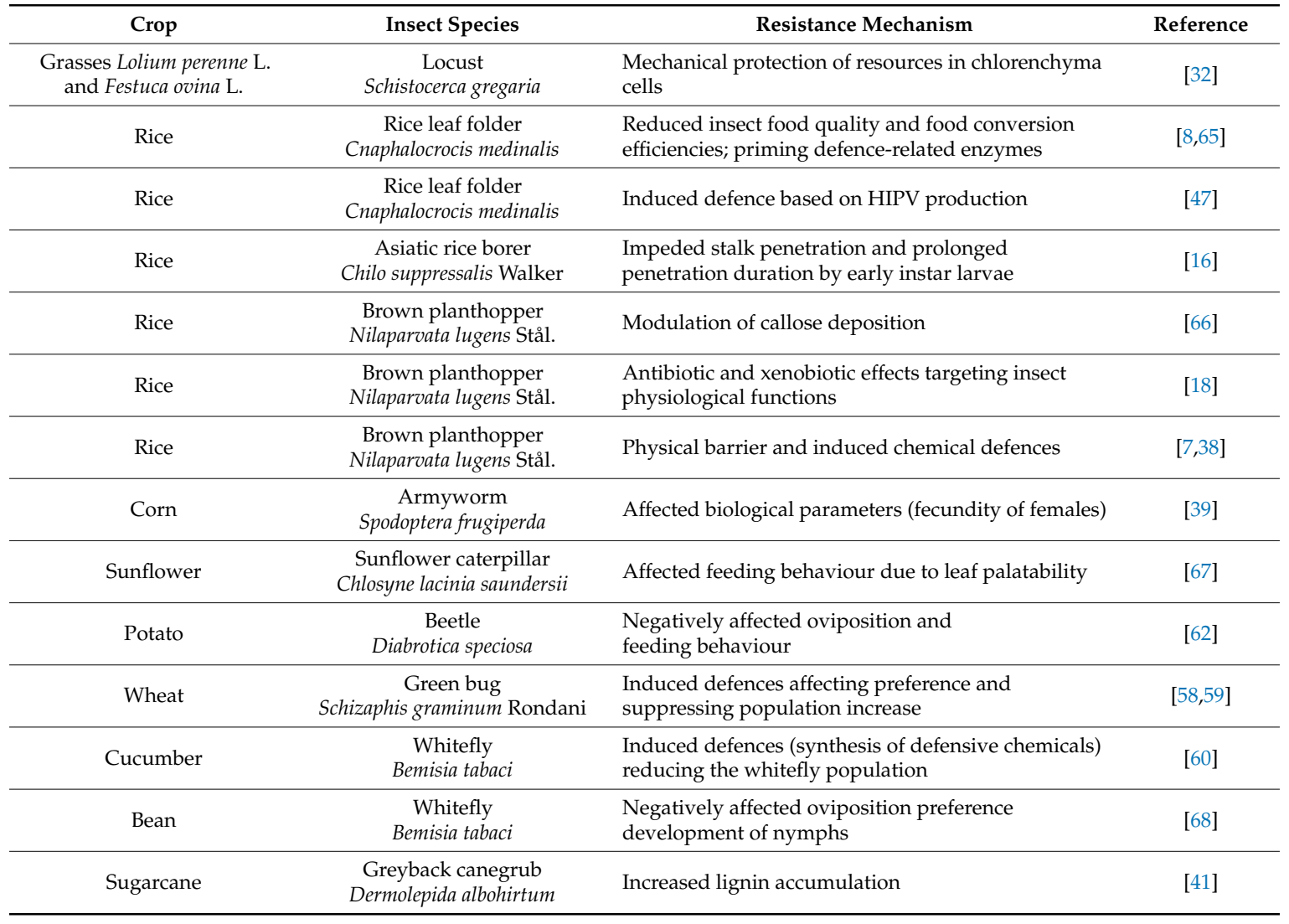

It also seems that Si-mediated mechanisms act similarly in plants both below and above ground, as $\mathrm{Si}$ induces lignin accumulation in the roots of both sugarcane (a monocot) [41] and oilseed rape (a eudicot) [37], increasing toughness and, eventually, resistance to insect attack [69]. Though the accumulation of Si differs among plant species, they likely display similar Si defence mechanisms against insects. Similarly, monocot and eudicot species seem to respond similarly to insect attack through similar Si-mediated mechanical and biochemical mechanisms. Accordingly, we predict that as-yet-untested insect pests may be affected in the same way as tested species. 
Generally, chewing insects and phloem-feeding insects (e.g., whitefly and aphids) induce distinct plant responses to attack. Chewing herbivores have stronger inductive effects than do sucking ones [70,71]. For example, compared with the chewing caterpillar Spodoptera exigua, the phloem feeder Bemisia tabaci did not induce the emission of HIPVs in Gossypium hirsutum [70,72]. Similarly, Spodoptera littoralis induced HIPV emissions whereas the aphid Rhopalosiphum maidis induced no measurable emissions even after heavy infestations in the monocot Zea mays [73]. Regardless of the effect magnitudes, Si affects both direct and indirect plant defences against both chewing and sucking insects, leading to similar impacts on biological parameters such as development time, immature survival and rate of population increase. Moreover, Han et al. [8] and Lang et al. [7] reported similar chemical defence responses via activation of the defensive enzyme that protects plants from stress in Si-amended rice infested with C. medinalis and $N$. lugens, respectively. However, there is little information on the role of $\mathrm{Si}$ mediated resistance through HIPVs induction against phloem feeding insects.

Chewing insects are more susceptible to Si physical barriers than are phloem feeders, as the latter may be able to avoid the phytoliths but we cannot dismiss the possibility that plant tissue injury resulting from the feeding itself may trigger the battery of Si-induced plant responses.

Further studies are therefore required to explore: Si-mediated resistance to insect pests in non-Si-accumulating plant species, both mechanical and biochemical mechanisms of insect pest resistance and the correlation between constitutive and induced resistance in which Si plays a role. Silicon, with all its remarkable protective plant defence effects, could be an eco-friendly alternative to conventional pesticides in IPM in agriculture.

Acknowledgments: The authors are greatly indebted to Tommy Landberg for providing us with scanning electron micrographs and to the International Rice Research Institute (IRRI) for providing us with valuable rice insect photos (http:/ / www.knowledgebank.irri.org).

Author Contributions: M.G. and F.A. conceived the idea of writing the review. F.A. collected the literature data and wrote the review. M.G. led the project.

Conflicts of Interest: The authors declare no conflicts of interest.

\section{References}

1. Kogan, M.; Lattin, J.D. Agricultural systems as ecosystems. In Handbook of Pest Management; Ruberson, J., Ed.; M. Dekker: New York, NY, USA, 1999; pp. 1-34. ISBN 0824794338.

2. Karban, R.; Baldwin, I.T. Induced Responses to Herbivory; University of Chicago Press: Chicago, IL, USA, 1997; ISBN 022642495 2/0 226424960.

3. Van Poecke, R.M.P.; Dicke, M. Induced parasitoid attraction by Arabidopsis thaliana: Involvement of the octadecanoid and the salicylic acid pathway. J. Exp. Bot. 2002, 53, 1793-1799. [CrossRef] [PubMed]

4. Howe, G.A.; Jander, G. Plant immunity to insect herbivores. Annu. Rev. Plant Biol. 2008, 59, 41-66. [CrossRef] [PubMed]

5. War, A.R.; Michael, G.P.; Tariq, A.; Abdul, A.B.; Barkat, H.; Savarimuthu, I.; Hari, C.S. Mechanisms of plant defense against insect herbivores. Plant Signal. Behav. 2012, 10, 1306-1320. [CrossRef] [PubMed]

6. Pappas, M.L.; Broekgaarden, C.; Broufas, G.D.; Kant, M.R.; Messelink, G.J.; Steppuhn, A.; Wäckersf, F.; van Dam, N.M. Induced plant defences in biological control of arthropod pests: A double-edged sword. Pest Manag. Sci. 2017, 73, 1780-1788. [CrossRef] [PubMed]

7. Lang, Y.; Han, Y.Q.; Li, P.; Li, F.; Ali, S.; Hou, M.L. Silicon amendment is involved in the induction of plant defense responses to a phloem feeder. Sci. Rep. 2017, 7, 4232. [CrossRef]

8. Han, Y.; Lei, W.; Wen, L.; Hou, M. Silicon-mediated resistance in a susceptible rice variety to the rice leaf folder, Cnaphalocrocis medinalis Guenée (Lepidoptera: Pyralidae). PLoS ONE 2015, 10, e0120557. [CrossRef] [PubMed]

9. Exley, C. Silicon in life: A bioinorganic solution to bioorganic essentiality. J. Inorg. Biochem. 1998, 69, 139-144. [CrossRef]

10. Episten, E. Silicon: Its manifold roles in plants. Ann. Appl. Biol. 2009, 155, 155-160. [CrossRef]

11. Ma, J.F.; Yamaji, N. Silicon uptake and accumulation in higher plants. Trends Plant Sci. 2006, 11, $392-397$. [CrossRef] [PubMed] 
12. Ma, J.F.; Takahashi, E. Silicon uptake and accumulation in plants. In Soil, Fertilizer and Plant Silicon Research in Japan, 1st ed.; Elsevier Science: Amsterdam, The Netherlands, 2002; pp. 73-106. ISBN 0444511660.

13. Ma, J.F. Role of silicon in enhancing the resistance of plants to biotic and abiotic stresses. Soil Sci. Plant Nutr. 2004, 50, 11-18. [CrossRef]

14. Liang, Y.; Miroslav, N.; Haijun, G.; Alin, S. Silicon and insect pest resistance. In Silicon in Agriculture; Yongchao, L., Miroslav, N., Richard, B., Haijun, G., Alin, S., Eds.; Springer: Berlin, Germany, 2015; pp. 197-204. ISBN 978-94-017-9977-5.

15. Kvedaras, O.L.; Keeping, M.G. Silicon impedes stalk penetration by the borer Eldana saccharina in sugarcane. Entomol. Exp. Appl. 2007, 125, 103-110. [CrossRef]

16. Hou, M.L.; Han, Y.Q. Si-mediated rice plant resistance to the Asiatic rice borer: Effects of silicon amendment and rice varietal resistance. J. Econ. Entomol. 2010, 103, 1412-1419. [CrossRef] [PubMed]

17. Dias, P.A.S.; Sampaio, M.V.; Rodrigues, M.P.; Korndorfer, A.P.; Oliveira, R.S.; Ferreira, S.E.; Korndörfer, G.H. Induction of resistance by silicon in wheat plants to alate and apterous morphs of Sitobion avenae (Hemiptera: Aphididae). Environ. Entomol. 2014, 43, 949-956. [CrossRef] [PubMed]

18. He, W.; Yang, M.; Li, Z.; Qui, J.; Liu, F.; Qu, X.; Qiu, Y.; Li, R. High levels of silicon provided as a nutrient in hydroponic culture enhances rice plant resistance to brown planthopper. Crop Prot. 2015, 67, 20-25. [CrossRef]

19. Parrella, M.P.; Costamagna, T.P.; Kaspi, R. The addition of potassium silicate to the fertilizer mix to suppress Liriomyza leafminers attacking chrysanthemums. Acta Hortic. 2007, 747, 365-369. [CrossRef]

20. Reynolds, O.L.; Keeping, M.G.; Meyer, J.H. Silicon-augmented resistance of plants to herbivorous insects: A review. Ann. Appl. Biol. 2009, 155, 171-186. [CrossRef]

21. Laing, M.D.; Gatarayiha, M.C.; Adandonon, A. Silicon use for pest control in agriculture. Proc. S. Afr. Sugar Technol. Assoc. 2006, 80, 278-286.

22. Nikpay, A.; Nejadian, E.S. Field applications of silicon-based fertilizers against sugarcane yellow mite Oligonychus sacchari. Sugar Tech. 2014, 16, 319-324. [CrossRef]

23. Fauteux, F.; Rémus-Borel, W.; Menzies, J.G.; Bélanger, R.R. Silicon and plant disease resistance against pathogenic fungi. FEMS Microbiol. Lett. 2005, 249, 1-6. [CrossRef] [PubMed]

24. Ye, M.; Song, Y.Y.; Long, J.; Wang, R.L.; Baeron, S.R.; Pan, Z.Q.; Salzman, K.Z.; Xie, J.F.; Cai, K.Z.; Luo, S.M.; et al. Priming of jasmonate-mediated antiherbivore defense responses in rice by silicon. Proc. Natl. Acad. Sci. USA 2013, 110, E3631-E3639. [CrossRef] [PubMed]

25. Nazaralian, S.; Majd, A.; Irian, S.; Najafi, F.; Ghahremaninejad, F.; Landberg, T.; Gregor, M. Comparison of silicon nanoparticles and silicate treatments in fenugreek. Plant Physiol. Biochem. 2017, 15, 25-33. [CrossRef] [PubMed]

26. Yoshida, S.; Ohnishi, Y.; Kitagishi, K. Histochemistry of Si in rice tissues. III. The presence of cuticle-silica double layer in the epidermal tissue. Soil Sci. Plant Nutr. 1962, 8, 1-51.

27. Massey, F.P.; Hartley, S.E. Physical defences wear you down: Progressive and irreversible impacts of silica on insect herbivores. J. Anim. Ecol. 2009, 78, 281-291. [CrossRef] [PubMed]

28. Dos Santos, M.; Junqueira, A.R.; de Sá, V.M.; Zanúncio, J.; Serrão, J. Effect of silicon on the morphology of the midgut and mandible of tomato leaf miner Tuta absoluta (Lepidoptera: Gelechiidae) larvae. ISJ 2015, 12, 158-165.

29. Sangster, A.G.; Hodson, M.J.; Tubb, H.J. Silicon deposition in higher plants. In Silicon in Agriculture; Datnoff, L.E., Snyder, G.H., Korndörfer, G.H., Eds.; Elsevier: Amsterdam, The Netherlands, 2001; pp. 85-113. ISBN 978-0-444-50262-9.

30. Smagghe, G.; Tirry, L. Insect midgut as a site for insecticide detoxification and resistance. In Biochemical Sites of Insecticide Action and Resistance; Ishaaya, I., Ed.; Springer: Berlin, Germany, 2001; pp. $293-321$. ISBN 978-3-642-59549-3.

31. Keeping, M.G.; Kvedaras, O.L.; Bruton, A.G. Epidermal silicon in sugarcane: Cultivar differences and role in resistance to sugarcane borer Eldana saccharina. Environ. Exp. Bot. 2009, 66, 54-60. [CrossRef]

32. Hunt, J.W.; Dean, A.P.; Webster, R.E.; Johnson, G.N.; Ennos, A.R. A novel mechanism by which silica defends grasses against herbivory. Ann. Bot. 2008, 102, 653-656. [CrossRef] [PubMed]

33. Pozza, A.A.A.; Alves, E.; Pozza, E.A.; Carvalho, J.G.; Montanari, M.; Guimarães, P.T.G.; Santos, D.M. Efeito do silício no controle da cercosporiose em três variedades de cafeeiro. Fitopatol. Bras. 2004, 29, 185-188. [CrossRef] 
34. Hartley, S.E.; Fitt, R.N.; McLarnon, E.L.; Wade, R.N. Defending the leaf surface: Intra- and inter-specific differences in silicon deposition in grasses in response to damage and silicon supply. Front. Plant Sci. 2015, 6, 35. [CrossRef] [PubMed]

35. Dorairaj, D.; Ismail, M.R. Distribution of silicified microstructures, regulation of cinnamyl alcohol dehydrogenase and lodging resistance in silicon and paclobutrazol mediated Oryza sativa. Front. Physiol. 2017, 8, 491. [CrossRef] [PubMed]

36. Handley, R.; Ekbom, B.; Agren, J. Variation in trichome density and resistance against a specialist insect herbivore in natural populations of Arabidopsis thaliana. Ecol. Entomol. 2005, 30, 284-292. [CrossRef]

37. Tissier, A. Glandular trichomes: What comes after expressed sequence tags? Plant J. 2012, 70, 51-68. [CrossRef] [PubMed]

38. Lang, Y.; Han, Y.; Li, P.; Wen, L.; Hou, M. Silicon amendment to rice plants impairs sucking behaviors and population growth in the phloem feeder Nilaparvata lugens (Hemiptera: Delphacidae). Sci. Rep. 2017, 7, 1101. Available online: http:/ / www.nature.com/articles/s41598-017-01060-4 (accessed on 24 April 2017).

39. Alvarenga, R.; Moraes, J.C.; Auad, A.M.; Coelho, M.; Nascimento, A.M. Induction of resistance of corn plants to Spodoptera frugiperda (J. E. Smith, 1797) (Lepidoptera: Noctuidae) by application of silicon and gibberellic acid. Bull. Entomol. Res. 2017, 107, 527-533. [CrossRef] [PubMed]

40. Frew, A.; Allsopp, P.G.; Gherlenda, A.N.; Johnson, S.N. Increased root herbivory under elevated atmospheric carbon dioxide concentrations is reversed by silicon-based plant defences. J. Appl. Ecol. 2016, 54, 1310-1319. [CrossRef]

41. Frew, A.; Powel, J.R.; Hiltpold, I.; Allsopp, P.G.; Sallam, N.; Johnson, S.N. Host plant colonisation by arbuscular mycorrhizal fungi stimulates immune function whereas high root silicon concentrations diminish growth in a soil-dwelling herbivore. Soil Biol. Biochem. 2017, 112, 117-126. [CrossRef]

42. Ali, J.G.; Agrawal, A.A. Specialist versus generalist insect herbivores and plant defense. Trends Plant Sci. 2012, 17, 293-302. [CrossRef] [PubMed]

43. De Vos, M.; Van Oosten, V.R.; Van Poecke, R.M.P.; Van Pelt, J.A.; Pozo, M.J. Signal signature and transcriptome changes of Arabidopsis during pathogen and insect attack. Mol. Plant Microbe Interact. 2005, 18, 923-937. [CrossRef] [PubMed]

44. Kessler, A.; Baldwin, I.T. Plant responses to insect herbivory: The emerging molecular analysis. Annu. Rev. Plant Biol. 2002, 53, 299-328. [CrossRef] [PubMed]

45. Kindt, F.; Joosten, N.N.; Peters, D.; Tjallingii, W.F. Characterisation of the feeding behaviour of western flower thrips in terms of electrical penetration graph (EPG) waveforms. J. Insect Physiol. 2003, 49, 183-191. [CrossRef]

46. Moran, P.J.; Thompson, G.A. Molecular responses to aphid feeding in Arabidopsis in relation to plant defense pathways. Plant Physiol. 2001, 125, 1074-1085. [CrossRef] [PubMed]

47. Liu, J.; Zhu, J.; Zhang, P.; Han, L.; Reynolds, O.L.; Zeng, R.; Wu, J.; Shao, Y.; You, M.; Gurr, G.M. Silicon supplementation alters the composition of herbivore induced plant volatiles and enhances attraction of parasitoids to infested rice plants. Front. Plant Sci. 2017, 8, 1265. [CrossRef] [PubMed]

48. Hartley, S.E.; DeGabriel, J.L. The ecology of herbivore-induced silicon defences in grasses. Funct. Ecol. 2016, 30, 1311-1322. [CrossRef]

49. Ghareeb, H.; Bozso, Z.; Ott, P.; Repenning, C.; Stahl, F.; Wydra, K. Transcriptome of silicon-induced resistance against Ralstonia solanacearum in the silicon non-accumulator tomato implicates priming effect. Physiol. Mol. Plant Pathol. 2011, 75, 83-89. [CrossRef]

50. Vivancos, J.; Labbe, C.; Menzies, J.G.; Belanger, R.R. Silicon-mediated resistance of Arabidopsis against powdery mildew involves mechanisms other than the salicylic acid (SA)-dependent defence pathway. Mol. Plant Pathol. 2015, 16, 572-582. [CrossRef] [PubMed]

51. Dicke, M.; Baldwin, I.T. The evolutionary context for herbivore-induced plant volatiles: Beyond the "cry for help". Trends Plant Sci. 2010, 15, 167-175. [CrossRef] [PubMed]

52. Van Poecke, R.M.P.; Dicke, M. Indirect defence of plants against herbivores: Using Arabidopsis thaliana as a model plant. Plant Biol. 2004, 6, 387-401. [CrossRef] [PubMed]

53. Van Oudenhove, L.; Mailleret, L.; Fauvergue, X. Infochemical use and dietary specialization in parasitoids: A meta-analysis. Ecol. Evol. 2017, 7, 4804-4811. [CrossRef] [PubMed]

54. Kvedaras, O.L.; An, M.; Choi, Y.S.; Gurr, G.M. Silicon enhances natural enemy attraction and biological control through induced plant defences. Bull. Entomol. Res. 2010, 100, 367-371. [CrossRef] [PubMed] 
55. Connick, V.J. The Impact of Silicon Fertilisation on the Chemical Ecology of Grapevine, Vitis vinifera; Constitutive and Induced Chemical Defences against Arthropod Pests and Their Natural Enemies. Master's Thesis, Charles Sturt University, Albury-Wodonga, NSW, Australia, 2011.

56. Pereira, R.R.C.; Moraes, J.C.; Prado, E.; Dacosta, R.R. Resistance inducing agents on the biology and probing behaviour of the greenbug in wheat. Sci. Agric. 2010, 67, 430-434. [CrossRef]

57. Hao, P.; Liu, C.; Wang, Y.; Chen, R.; Tang, M.; Du, B.; Zhu, L.; He, G. Herbivore-induced callose deposition on the sieve plates of rice: An important mechanism for host resistance. Plant Physiol. 2008, 146, 1810-1820. [CrossRef] [PubMed]

58. Gomes, F.B.; Jair, C.D.M.; Custódio, D.D.S.; Márcio, M.G. Resistance induction in wheat plants by silicon and aphids. Sci. Agric. 2005, 62, 547-551. [CrossRef]

59. Costa, R.R.; Moraes, J.C.; DaCosta, R.R. Feeding behaviour of the greenbug Schizaphis graminum on wheat plants treated with imidacloprid and/or silicon. J. Appl. Entomol. 2011, 135, 115-120. [CrossRef]

60. Correa, R.S.B.; Moraes, J.C.; Auad, A.M.; Carvalho, G.A. Silicon and acibenzolar-S-methyl as resistance inducers in cucumber, against the whitefly Bemisia tabaci (Gennadius) (Hemiptera: Aleyrodidae) biotype B. Neotrop. Entomol. 2005, 34, 429-433. [CrossRef]

61. Lu, J.; Robert, C.A.; Riemann, M.; Cosme, M.; Mène-Saffrané, L.; Massana, J.; Stout, M.J.; Lou, Y.; Gershenzon, J.; Erb, M. Induced jasmonate signaling leads to contrasting effects on root damage and herbivore performance. Plant Physiol. 2015, 167, 1100-1116. [CrossRef] [PubMed]

62. Assis, F.A.E.; Jair, C.M.; Luis, C.P.S.; Jonas, F.; Amanda, M.N.; Cristiana, S.A. Inducers of resistance in potato and its effects on defoliators and predatory insects. Rev. Colomb. Entomol. 2012, 38, 30-34.

63. Olli, S.; Kirti, P.B. Cloning, characterization and antifungal activity of defensin Tfgd1 from Trigonella foenum-graecum L. J. Biochem. Mol. Biol. 2006, 39, 278-283. [CrossRef] [PubMed]

64. Kuai, J.; Sun, Y.; Guo, C.; Zhao, L.; Zuo, Q.; Wu, J.; Zhou, G. Root-applied silicon in the early bud stage increases the rapeseed yield and optimizes the mechanical harvesting characteristics. Field Crop. Res. 2017, 200, 88-97. [CrossRef]

65. Han, Y.; Li, P.; Gong, S.; Yang, L.; Wen, L.; Hou, M. Defense responses in rice induced by silicon amendment against infestation by the leaf folder Cnaphalocrocis medinalis. PLoS ONE 2016, 11, e0153918. [CrossRef] [PubMed]

66. Hou, M.; Yang, L.; Han, Y.Q.; Li, P. Improved resistance to the brown planthopper in rice plants amended with silicon and the underlying mechanisms. In Proceedings of the 7th International Conference on Silicon in Agriculture, UAS, Bengaluru, India, 24-28 October 2017.

67. Assis, F.A.; Moraes, J.C.; Auad, A.M.; Coelho, M. The effects of foliar spray application of silicon on plant damage levels and components of larval biology of the pest butterfly Chlosyne lacinia saundersii (Nymphalidae). Int. J. Pest Manag. 2013, 59, 128-134. [CrossRef]

68. Peixtot, M.L.; Moraes, J.C.; Silva, A.A.; Assis, F.A. Effect of silicon on the oviposition preference of Bemisia tabaci Biotype B (GENN.) (Hemiptera: Aleyrodidae) on bean (Phaseolus vulgaris L.) plants. Cienc. Agrotec. 2011, 35, 478-481. [CrossRef]

69. Johnson, S.N.; Rasmann, S.; Hallett, P.D.; Gillespie, T.L.; Halpin, C. Below-ground herbivory and root toughness: A potential model system using lignin-modified tobacco. Physiol. Entomol. 2010, 35, 186-191. [CrossRef]

70. Saona, C.R.; Musser, R.O.; Vogel, H.; Sue, M.H.M.; Jennifer, S.T. Molecular, biochemical, and organismal analyses of tomato plants simultaneously attacked by herbivores from two feeding guilds. J. Chem. Ecol. 2010, 36, 1043-1057. [CrossRef] [PubMed]

71. Li, X.; Meng, L.; Xing, G.; Li, B. Constitutive and induced resistance in soybean interact to affect performance of a herbivore and its parasitoid. Biol. Control 2016, 101, 145-151. [CrossRef]

72. Saona, C.R.; Crafts, S.J.; Cañas, L.A. Volatile emissions triggered by multiple herbivore damage: Beet armyworm and whitefly feeding on cotton plants. J. Chem. Ecol. 2003, 29, 2539-2550. [CrossRef]

73. Turlings, T.C.J.; Marco, B.; Rinaldo, B.; Franz, B.; Genevieve, C.; Silvia, D. The induction of volatile emissions in maize by three herbivore species with different feeding habits: Possible consequences for their natural enemies. Biol. Control 1998, 11, 122-129. [CrossRef]

(C) 2018 by the authors. Licensee MDPI, Basel, Switzerland. This article is an open access article distributed under the terms and conditions of the Creative Commons Attribution (CC BY) license (http://creativecommons.org/licenses/by/4.0/). 